\title{
PENGARUH NET PROFIT MARGIN, DEBT TO EQUITY RATIO DAN PRICE TO BOOK VALUE TERHADAP HARGA SAHAM
}

\author{
Amirullah \\ Sekolah Tinggi Ilmu Ekonomi Indonesia Malang \\ amirullahmenulis@gmail.com \\ Rizki Rahmawati \\ Sekolah Tinggi Ilmu Ekonomi Indonesia Malang \\ rizki_rm@gmail.com
}

\begin{abstract}
Abstrak: This research report aims to present the results of a study entitled the effect of net profit margin, debt to equity ratio and price to book value on stock prices in construction and building companies listed on the Indonesia Stock Exchange. The research sample consisted of 6 companies, namely construction and building companies in the period 2013 to 2017. Samples were taken using the purposive sampling method. The data analysis technique used is multiple linear regression analysis. Based on the results of hypothesis testing ( $F$ test) simultaneously the variable net profit margin, debt to equity ratio and price to book value have a positive and significant effect on stock prices. Partially the results ( $t$ test) of net profit margin and price to book value have a negative effect but are significant to stock prices. While the debt to equity ratio has a negative effect but not significant to stock prices.
\end{abstract}

Kata Kunci : net profit margin ; debt to equity ratio ; price to book value ; tock price

\section{PENDAHULUAN}

Peran pasar modal sangat penting bagi perusahaan untuk penyediaan sumber pembelanjaan jangka panjang. Dengan adanya pasar modal diharapkan aktivitas perekonomian menjadi meningkat pesat karena pasar modal merupakan alternatif pendanaan bagi semua perusahaan-perusahaan (Darmadji, 2001:2).

Pasar modal merupakan instrumen keuangan atau sekuritas jangka panjang yang bisa diperjual belikan, baik dalam bentuk hutang ataupun modal sendiri, baik yang diterbitkan oleh pemerintah, public authorities, maupun perusahaan swasta (Husnan, 2001:3). Pasar modal menggalang pergerakan dana jangka panjang dari masyarakat (investor) yang kemudian disalurkan pada sektor-sektor yang produktif dengan harapan sektor tersebut dapat berkembang dan menghasilkan lapangan pekerjaan yang baru bagi masyarakat.

Harga saham terbentuk melalui mekanisme permintaan dan penawaran pasar modal. Apabila suatu saham mengalami kelebihan permintaan maka harga saham cenderung naik. Sebaliknya, apabila suatu saham mengalami kelebihan penawaran maka harga saham cenderung turun. Jika harga saham suatu perusahaan selalu mengalami peningkatan, maka investor akan 
menilai bahwa perusahaan tersebut berhasil dalam mengelola usahanya. Jika sebaliknya maka investor tidak akan menanamkan modalnya di perusahaan tersebut.

Bagi investor, laporan keuangan tahunan merupakan sumber berbagai macam informasi khususnya neraca dan laporan laba rugi perusahaan. Oleh sebab itu, publikasi laporan keuangan peusahaan (emiten) sangat di tunggu oleh para investor di pasar modal. Studi di masa lalu telah menunjukkan pentingnya laporan keuangan tahunan perusahaan sebagai sumber untuk investasi( Sunarto,2001).

Para investor adalah mereka yang menerapkan konsep "think fast and decision fast" atau berpikir cepat dan mengambil keputusan secara cepat. Karena faktor itu maka investor menginginkan penggunaan rasio keuangan yang dianggap lebih fleksibel dan sederhana namun mampu memberi jawaban yang mereka inginkan. ( Fahmi, 2011:115) harga saham dapat dipengaruhi olehNet Profit Margin. Jika tingkat NPM tinggi, maka semakin baik kinerja perusahaan (Hendri, 2015). Faktor lainnyayang mempengaruhi harga saham adalah struktur modal. Struktur modal bertujuan untuk memadukan sumber dana permanen yang selanjutnya akan digunakan perusahaan dengan cara yang diharapkan mampu memaksimumkan nilai perusahaan (Weston dan Copeland, 2010:319). Harga saham mencerminkan nilai perusahaan, dengan demikian jika nilai suatu perusahaan meningkat, maka harga saham perusahaan tersebut juga akan naik (Sudana, 2011:143).

Apabila posisi struktur modal berada diatas target struktur modal optimalnya, maka setiap pertambahan hutang akan menurunkan nilai perusahaan. Penentuan target struktur modal optimal adalah salah satu dari tugas utama manajemen perusahaan. Selanjutnya, Price to Book Value salah satu faktor fundamental dari sebuah saham yang banyak digunakan oleh investor maupun analis untuk mengetahui nilai wajar saham. Saham perusahaan yang go public merupakan komoditi investasi yang tergolong berisiko tinggi, karena sifat komoditinya sangat peka terhadap perubahan-perubahan yang terjadi, baik perubahan di luar negeri atau perubahan di dalam negeri. Indonesia sebagai negara kepulauan juga memiliki kekayaan alam yang cukup luas terutama pada sektor pertambangan seperti batu bara, minyak bumi dan lain-lain.

Ketika harga saham Semen Indonesia mengalami fluktuasi dapat berpengaruh terhadap harga saham sub sektor konstruksi dan bangunan terutama PT. Pembangunan Perumahan (persero) Tbk, yang IPO pada tahun 2010 dimana PT. Semen Indonesia sebagai salah satu perusahaan semen yang terhubung langsung dengan PT. Pembangunan Perumahan (persero) Tbk, sebagai konsumen dan memiliki faktor yang mempengaruhi fluktuasi harga saham secara internal. Namun demikian perusahaan di sektor Konstruksi dan Bangunan tidak selalu mengalami kenaikan. Tabel 1 memperlihatkan beberapa perusahaan yang harga sahamnya mengalami fluktuasi dan penurunan.

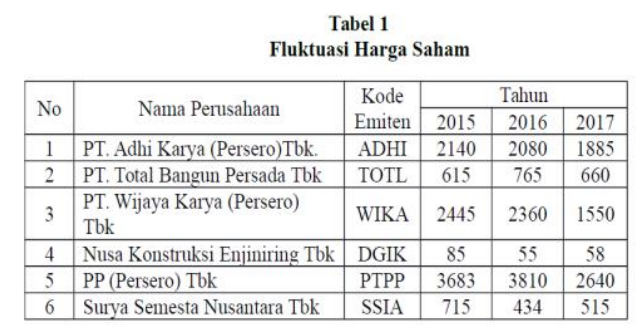

Sumber: Bursa Efek Indonesia (data diolah) 


\section{TINJAUAN PUSTAKA}

\section{Laporan Keuangan Perusahaan}

Laporan keuangan terdiri dari neraca, laporan rugi-laba, laporan perubahan modal dan laporan arus kas. Tetapi, sesuai dengan pernyataan standar akuntansi keuangan No. 1 (revisi 2009) tentang penyajian laporan keuangan terdiri dari beberapa komponen, yaitu: (a) laporan posisi keuangan pada akhir periode; (b) laporan laba rugi komprehensif selama periode; (c) laporan perubahan ekuitas selama periode; (d) laporan arus kas selama periode; (e) catatan atas laporan keuangan.

Harahap

(2011:190)

mengungkapkan analisis laporan keuangan berarti menguraikan pospos laporan keuangan menjadi unit informasi yang lebih kecil dan melihat hubungannya yang bersifat signifikan atau yang mempunyai makna antara satu dengan yang lain baik antara data kuantitatif maupun data non-kuantitatif dengan tujuan untuk mengetahui kondisi keuangan lebih dalam yang sangat penting dalam proses menghasilkan keputusan yang tepat. Tujuan analisis laporan keuangan mempunyai maksud untuk menegaskan apa yang diinginkan atau diperoleh dari analisis yang dilakukan. Dengan adanya tujuan, analisis selanjutnya akan dapat terarah, memiliki batasan dan hasil yang ingin dicapai.

\section{Analisis Rasio Keuangan}

Untuk mengetahui apakah keadaan keuangan perusahaan dalam kondisi yang baik dapat dilakukan berbagai analisa, salah satunya adalah analisis rasio. Analisis rasio adalah membandingkan antara unsurunsur neraca, unsur-unsur laba rugi, unsur-unsur neraca dan laporan laba rugi, serta rasio keuangan emiten yang satu dan rasio keuangan emiten yang lainnya (Mohamad Samsul, 2006). Menurut Kasmir (2015:104) rasio keuangan merupakan kegiatan yang membandingkan angka-angka yang ada dalam laporan keuangan dengan cara membagi suatu angka dengan angka lainnya. Perbandingan dapat dilakukan antara suatu kompenen dengan kompenen dalam satu laporan keuangan atau antara kompenen yang ada diantara laporan keuangan, kemudian angka yang diperbandingkan dapat berupa angka-angka dalam satu periode maupun beberapa periode.

Pendapat lain dikemukakan Helfret (1999) bahwa analisa rasio keuangan merupakan instrumen analisis prestasi perusahaan yang menjelaskan berbagai hubungan dan indikator keuangan yang ditujukan untuk menunjukkan perubahan dalam kondisi keuangan atau prestasi operasi di masa lalu. Makna dan kegunaan rasio keuangan dalam praktik bisnis pada kenyataannya bersifat subyektif, bergantung bagaimana suatu analisis dilakukan dalam konteks analisis tersebut diaplikasikan.

Klasifikasi rasio menurut Syamsuddin (2007:40) yaitu : 1) Rasio likuiditas yang dipergunakan untuk mengukur kemampuan perusahaan dalam memenuhi kewajiban jangka pendek, 2) Rasio aktivitas yaitu untuk mengukur seberapa efektif perusahaan menggunakan sumber dayanya, 3) Rasio profitabilitas yaitu untuk mengukur seberapa efektif perusahaan untuk menghasilkan laba selama periode tertentu. Sedangkan Rahardjo (2009), rasio profitabilitas terdiri dari beberapa ratio, yaitu ROA, ROE, ROCE, EVA, Value Added Ratio, Gross Profit Margin, 
Operating Profit Margin, Net Profit Margin, dan Operating Ratio.

Net Profit Margin (NPM)

Menurut Kasmir (2012:200) margin laba bersih merupakanukuran keuntungan dengan membandingkan antara laba setelah bunga dan pajak dibandingkan dengan penjualan. Rasio ini menunjukkan pendapatan bersih perusahaan atas penjualan. Menurut Werner R. Murhadi (2013:64) Net Profit Margin adalah mencerminkan kemampuan perusahaan dalam menghasilkan laba neto dari setiap penjualannya. Semakin tinggi nilai NPM maka menunjukkan semakin baik.

Net Profit Margin (NPM) merupakan rasio antara laba bersih (net profit) yaitu penjualan sesudah dikurangi dengan seluruh expenses termasuk pajak dibandingkan dengan penjualan. Semakin tinggi Net Profit Margin, semakin baik operasi suatu perusahaan (Syamsuddin, 2011:62).

Menurut Alexandri (2008:200) Net Profit Margin (NPM) adalah rasio yang digunakan untuk menunjukkan kemampuan perusahaan dalam menghasilkan keuntungan bersih setelah dipotong pajak. Sedangkan menurut Rahardjo (2009) Net Profit Margin (NPM) adalah perbandingan antara laba bersih (laba sesudah biaya bunga dan pajak) dengan penjualan bersih perusahaan. Dengan rumus sebagai berikut :

$$
\begin{aligned}
& \text { Net Profit } \\
& \text { Margin } \frac{\text { Laba Bersih }}{\text { Penjualan Bersih }}
\end{aligned}
$$

\section{Debt to Equty Ratio}

Pada penelitian ini struktur modal diproksikan dengan Debt to Equity Ratio (DER). Menurut Mulyadi (2006:139) DER menggambarkan perbandingan antara total hutang dengan total ekuitas perusahaan yang digunakan sebagai sumber pendanaan usaha. Semakin besar DER menandakan struktur permodalan usaha lebih banyak memanfaatkan utang-utang relatif terhadap ekuitas dan mencerminkan risiko perusahaan yang relatif tinggi. Rasio ini dicari dengan membandingkan antara seluruh hutang, termasuk utang lancar dengan seluruh ekuitas. Sedangkan menurut Rahardjo (2009:139) DER merupakan perbandingan antara jumlah seluruh hutang (baik jangka pendek maupun jangka panjang) dengan jumlah modal perusahaan sendiri. Rumus yang digunakan sebagai berikut :

Debt to Equity

$$
\text { Ratio }=\frac{\text { Total Hutang }}{\text { Modal Sendiri }}
$$

\section{Price to Book Value}

Nilai buku (book value) per lembar saham menunjukkan aktiva bersih (net asset) yang dimiliki oleh pemegang saham dengan memiliki satu lembar saham. Karena aktiva bersih adalah sama dengan total ekuitas pemegang saham, maka nilai buku per lembar saham adalah total ekuitas dibagi dengan jumlah saham yang beredar (Jogiyanto 2003:82)

Menurut Husnan. S dan Pudjiastuti (2006 : 258), rumus yang digunakan untuk menghitung Price to Book Value adalah sebagai berikut :

$$
\begin{aligned}
& \text { Price to Book } \\
& \qquad \text { Value }=\frac{\text { Harga Pasar }}{\text { Nilai Buku Saham }}
\end{aligned}
$$

Untuk mencari nilai buku per lembar saham (book value per share)dapatdihitung dengan cara:

Rumus

$$
\begin{aligned}
& \text { BVPS } \\
& =\frac{\text { Jumlah Modal }}{\text { Jumlah Lembar Saham }}
\end{aligned}
$$

\section{Harga Saham}

Saham adalah surat berharga 
sebagai bukti penyertaan atau pemilikan individu maupun institusi yang dikeluarkan oleh sebuah perusahaan yang berbentuk Perseroan Terbatas (Sunariyah, 2006:127). Pendapat lain dikemukakan oleh Darmadji dan Fakhruddin (2012:102) bahwa harga saham adalah Harga yang terjadidi bursa pada waktu tertentu. Harga saham bias berubah naik atau pun turun dalam hitungan waktu yang begitu cepat. Ia dapat berubah dalam hitungan menit bahkan dapat berubah dalam hitungan detik. Haltersebut dimungkinkan karena tergantung dengan permintaan dan penawaran antara pembeli saham dan penjual saham.

Harga saham dibedakan menjadi tiga, yaitu: 1) Harga nominal,2) Harga perdana dan 3) Harga pasar (Widoatmojo,2005:84). Harga saham dapat ditentukan berdasarkan nilai buku (book value), nilai pasar (market value), dan nilai intrinsik (intrinsic value), (Jogiyanto, 2009). Nilai buku merupakan nilai saham menurut pembukuan perusahaan emiten. Nilai pasar merupakan nilai saham di pasar saham dan nilai intrinsik merupakan nilai yang sebenarnya dari saham. Nilai pasar merupakan harga saham yang terjadi di pasar bursa pada saat tertentu yang ditentukan oleh pelaku pasar (Jogiyanto, 2009). Harga pasar saham terbentuk melalui mekanisme permintaan dan penawaran di pasar modal (Agus Sartono, 2008). Sedangkan harga pasar saham menurut Anoraga dan Pakarti (2003) harga pasar merupakan harga dari suatu saham pada pasar yang sedang berlangsung atau jika pasar sudah ditutup, maka harga pasar adalah harga penutupnya (closing price).

Berdasarkan sejumlah teori yang

di sajikan di atas, maka kerangka konsep penelitian yang dikembangkan dapat digambarkan sebagai berikut:

Gambar 2. Kerangka Konseptual

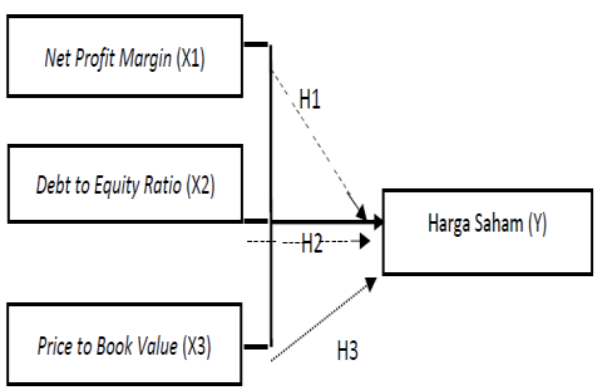

\section{METODE PENELITIAN}

Populasi yang diamati dan dianalisis adalah perusahaan manufaktur di sektor aneka industi dengan sub sektor industri Konstruksi dan Bangunan yang terdaftar di Bursa Efek Indonesia pada tahun 2013-2017, yaitu sebanyak 9 perusahaan. Dalam penelitian ini, sampel yang digunakan adalah dengan menggunakan metode purposive sampling, Berdasarkan kriteria yang telah ditentukan, maka sampel yang dianalisis berjumlah 6 perusahaan. Adapun dibawah ini perincian dalam pemilihan sampel :

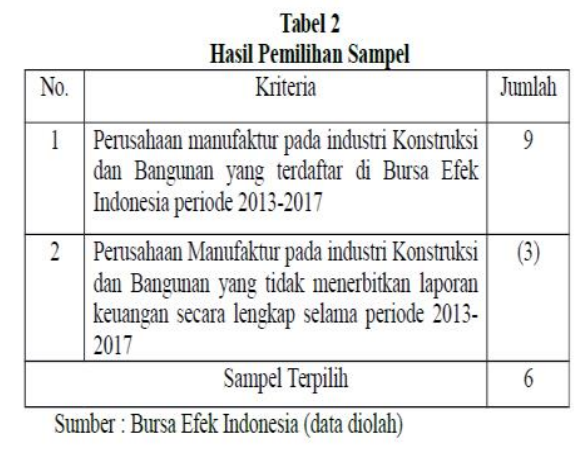

Dengan demikian, terpilihlah perusahaan-perusahaan manufaktur pada industri Konstruksi dan Bangunan yang menjadi sampel adalah sebagai berikut : 


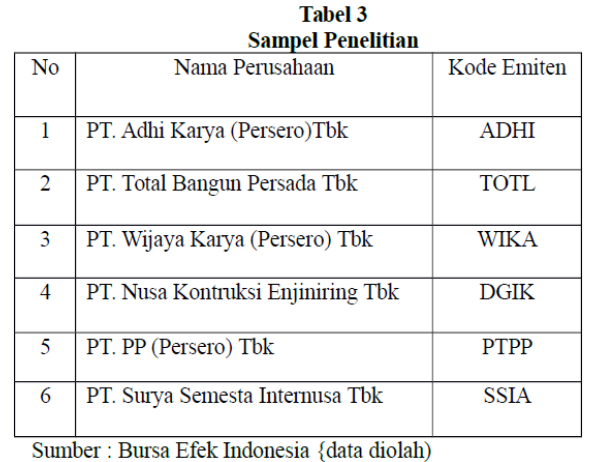

Uji regresi linear berganda digunakan untuk melakukan prediksi bagaimana perubahan variabel dependen bila nilai variabel independen dinaikkan atau di turunkan nilainya.Adapun model analisis dalam penelitian ini adalah :

$$
\mathrm{Y}=\alpha+\mathrm{b}_{1} \mathrm{NPM}+\mathrm{b}_{2} \mathrm{DER}+\mathrm{b}_{3} \mathrm{PBV}+\mathrm{e}
$$

Dimana :

$$
\begin{aligned}
& \mathrm{Y}=\text { Harga Saham } \\
& \alpha=\text { Koefisien Konstanta } \\
& \mathrm{b}_{1}=\text { Koefisien Variabel Bebas (NPM) } \\
& \mathrm{b}_{2}=\text { Koefisien Variabel Bebas (DER) } \\
& \mathrm{b}_{3}=\text { Koefisien Variabel Bebas (PBV) } \\
& \mathrm{e}=\text { Koefisien Pengganggu }
\end{aligned}
$$

Uji $\mathrm{t}$ ini dilakukan untuk menguji pengaruh masing-masing variabel independen yang digunakan terhadap variabel dependen secara parsial.Uji $F$ ini dilakukan untuk menguji pengaruh semua variabel independen terhadap variabel dependen.

\section{HASIL DAN PEMBAHASAN}

Uji koefisien determinasi disajikan dalam tabel 4 berikut ini :

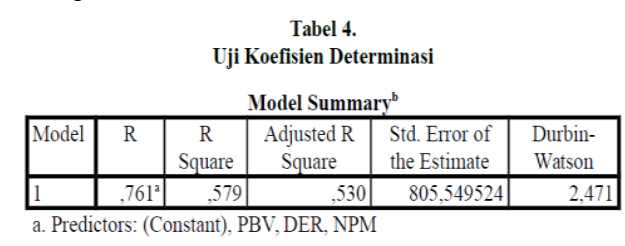

Gambar 4 menunjukkan bahwa nilai adjusted $\mathrm{R}^{2}$ sebesar 0,530. Nilai tersebut menunjukkan bahwa variabel harga saham dipengaruhi oleh variabel Net profit Margin, Debt To Equity Ratio dan Price to Book Value sebesar 53\%, sehingga sebesar $47 \%$ (100\%-53\%) ditentukan oleh variabel lain yang tidak diikutkan dalam penelitian ini.

$$
\text { Dengan menggunakan }
$$

Unstandardized beta Coefficients variabel independen tidak memiliki unit ukuran, semuanya menggunakan persentase (\%). Uji t dapat dilihat pada tabel 5

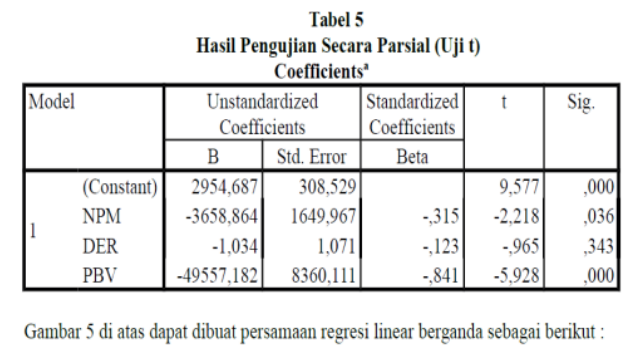

Gambar 5 di atas dapat dibuat persamaan regresi linear berganda sebagai berikut :

$Y=2954,687-3658,864 X_{1}-1,034$ $\mathrm{X}_{2}-\mathbf{4 9 5 5 7 , 1 8 2} \mathrm{X}_{3}+\mathrm{e}$

Koefisien-koefisien persamaan regresi linear berganda diatas dapat diartikan sebagai berikut :

1) Nilai konstanta 2954,687 menunjukkan jika variabel independen yang terdiri dari Net Profit Margin, Debt to Equity Ratio dan Price to Book Value = 0 , maka variabel harga saham sebesar 2954,687.

2) Nilai koefisien Net Profit Margin sebesar $\quad-3658,864$ bertanda negative (berlawanan). Hal ini menunjukkan jika variable Net Profit Margin turun maka harga saham akan turun. Dengan kata lain jika NPM turun sebesar satu satuan maka harga saham akan juga turun sebesar yaitu $-3658,864$. penurunan tersebut terjadi dengan asumsi variabel 
independen yang lain dari model regresi adalah tetap.

3) Nilai koefisien Debt to Equity Ratio sebesar $-1,034$ bertanda negatif (berlawanan). Hal ini menunjukkan jika variable Debt to Equity Ratio meningkat akan diikuti dengan penurunan harga saham. Dengan kata lain jika tingkat DER sebesar satu satuan maka harga saham akan turun sebesar yaitu 1,034 dengan asumsi variabel yang lainnya tetap.

4) Nilai koefisien Price to Book Value sebesar $\quad-49557,182$ bertanda negative (berlawanan). Hal ini menunjukkan jika variable Price to Book Value turun maka harga saham akan turun. Dengan kata lain jika Price to Book Value turun sebesar satu satuan maka harga saham akan juga turun sebesar yaitu $-49557,182$. penurunan tersebut terjadi dengan asumsi variabel independen yang lain dari model regresi adalah tetap.

Hasil pengujian secara simultan (uji F) dapat dilihat pada tabel 6 berikut ini :

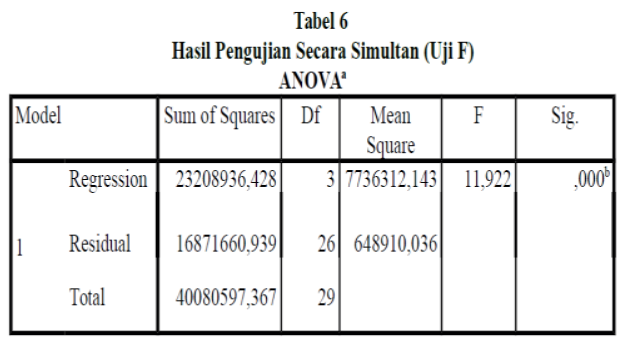

Dari hasil pengujian uji $F$ yang terdapat di tabel 6 diperoleh $\mathrm{F}$ hitung sebesar 11,922 dengan nilai signifikansi sebesar $0,000<\alpha$ $(\alpha=0,05)$. Maka dinyatakan bahwa variabel independen yaitu Net Profit Margin, Debt to Equity Ratio dan Price to Book Value secara bersamasama berpengaruh terhadap variabel dependen yaitu harga saham. Maka persamaan regresi yang diperoleh dapat diandalkan atau model yang digunakan sudah fix.

Hasil analisis data yang diungkapkan di atas dapat dijelaskan sebagai berikut:

1. Pengaruh Net Profit Margin secara parsial terhadap Harga Saham

Berdasarkan hasil uji $t$ yang dilakukan diatas, menunjukkan bahwa variabel Net Profit Margin nilai t hitung sebesar -2,218 dengan angka signifikansinya sebesar 0,036 . Jika dibandingkan dengan angka signifikansi yang ditetapkan $(0,05)$, menunjukkan bahwa nilai signifikansinya $(0,036)<0,05$, maka $\mathrm{H}_{0}$ diterima. Sehingga variabel Net Profit Margin berpengaruh positif dan signifikan terhadap harga saham. Ini berarti kemampuan perusahaan untuk mendapat laba juga tinggi, semakin tinggi tingkat penjualan maka semakin produktif perusahaan tersebut untuk memperoleh laba yang tinggi. Sehingga hal ini akan meningkatkan kepercayaan investor untuk menginvestasikan modalnya pada perusahaan tekstil dan garmen sehingga permintaan akan saham perusahaan meningkat yang otomatis akan diikuti peningkatan harga saham tersebut. Penelitian tersebut juga mendukung penelitian oleh Nana Umdiana dan Jenisya (2016) bahwa NPM berpengaruh signifikan terhadap harga saham.

2. Tidak berpengaruhDebt to Equity Ratiosecara parsial terhadap Harga Saham

Berdasarkan hasil uji $\mathrm{t}$ yang 
dilakukan di atas, menunjukkan bahwa variabel Debt to Equity Ratio nilai $\mathrm{t}$ hitung sebesar 0,965 dengan angka signifikansinya sebesar 0,343 . Jika dibandingkan dengan angka signifikansi yang ditetapkan $(0,05)$, menunjukkan bahwa nilai signifikansi $(0,343)>0,05$ maka $\mathrm{H}_{0}$ ditolak. Sehingga variabel Debt to Equity Ratio berpengaruh negatif dan tidak signifikan terhadap harga saham. Ini bukan berarti bahwa perusahaan dapat menentukan tingkat proporsi hutang setinggitingginya, karena proporsi hutang yang semakin besar akan menimbulkan resiko yang besar pula bagi perusahaan dan juga investor. Sehingga hal ini investor tidak tertarik dengan perusahaan yang memiliki tingkat hutang yang tinggi karena berpotensi menghasilkan resiko yang tinggi pula. Maka hal itu investor enggan membeli saham perusahaan konstruksi dan bangunan yang disebabkan pada umumnya investor menghindari resiko yang tinggi. Jika nilai DER tinggi maka semakin buruk nilai perusahaan konstruksi dan bangunan berjalan karena nilai perusahaan mencerminkan kondisi perusahaan tersebut dalam membayar hutangnya dan sebaliknya jika nilai DER rendah maka semakin baik nilai perusahaan berjalan Wuryaningrum (2015). Penelitian tersebut juga mendukung penelitian oleh Aulia Mandasari (2014), yang menyatakan bahwa Debt to Equity Ratio berpengaruh tidak signifikan terhadap harga saham.
3. Pengaruh Price to Book Value secara parsial terhadap Harga Saham

Berdasarkan hasil uji $\mathrm{t}$ yang dilakukan di atas, menunjukkan bahwa variabel Price to Book Value nilai t hitung sebesar 5,928 dengan angka signifikansinya sebesar 0,000 . Jika dibandingkan dengan angka signifikansi yang ditetapkan $(0,05)$, menunjukkan bahwa nilai signifikansi $(0,000)<0,05$, maka $\mathrm{H}_{0}$ diterima. Ini artinya bahwa kinerja keuangan perusahaan dalam hal ini sangat baik sehingga semakin tinggi nilai Price to Book Value .berarti pasar saham perusahaan tersebut akan meningkat pula begitupun sebaliknya. Dengan demikian variabel Price to Book Value berpengaruh positif dan signifikan terhadap harga saham. Penelitian tersebut juga mendukung penelitian oleh E. Amaliah Itabillah (2013) yang menyatakan bahwa Price to Book Value berpengaruh signifikan terhadap harga saham.

4. Pengaruh Net Profit Margin, Debt to Equity Ratio Dan Price to Book Value terhadap Harga Saham.

Berdasarkan hasil uji $\mathrm{F}$ yang dilakukan di atas, menunjukkan bahwa hasil pengujian uji $\mathrm{F}$ yang diperoleh $\mathrm{F}$ hitung sebesar 11,922 dengan nilai signifikansi sebesar $0,000<\alpha \quad(\alpha=0,05)$. Maka dinyatakan bahwa variabel independen yaitu Net Profit Margin, Debt to Equity Ratio dan Price to Book Value secara bersama-sama berpengaruh terhadap variabel dependen yaitu harga saham. 


\section{KESIMPULAN}

Sejalan dengan tujuan penelitian, kesimpulan penelitian ini yaitu variabel Net Profit Margin dan Price to Book Value secara parsial berpengaruh signifikan terhadap harga saham. Net Profit Margin dan Price to Book Value mempunyai pengaruh yang signifikan terhadap harga saham pada perusahaan konstruksi dan bangunan. Sedangkan variabel Debt to Equity Ratio secara parsial berpengaruh tidak signifikan terhadap harga saham. Debt to Equity Ratiotidak berpengaruh signifikan terhadap harga saham pada perusahaan konstruksi dan bangunan yang terdaftar di BEI periode tahun 2013-2017.

Variabel Net Profit Margin, Debt to quity Ratio dan Price to Book Value secara simultan berpengaruh signifikan terhadap harga saham. Net Profit Margin, Debt to Equity Ratio dan Price to Book Value mempunyai pengaruh yang signifikan terhadap harga saham pada perusahaan konstruksi dan bangunan yang terdaftar di BEI periode tahun 2013-2017.

\section{IMPLIKASI}

Implikasi teoritis dalam penelitian ini adalah harga saham pada perusahaan properti pada sektor konstruksi dan bangunan yang terdaftar di Bursa Efek Indonesia dipengaruhi oleh tiga faktor, yaitu Net Profit Margin, Debt to Equity Ratio dan Price to Book Valuetetapi faktor ekonomi yang paling dominan pengaruhnya. Hal ini menegaskan bahwa walaupun ketiga faktor tersebut penting. Sedangkan implikasi manajerial yang bisa di adopsi oleh para manajer sektor konstruksi dan bangunan khususnya dalam rangka meningkatkan harga saham adalah dengan memperhatikan faktor-faktor Net Profit Margin, Debt to Equity Ratio dan Price to Book Value. Mengingat bahwa faktor Net Profit Margin, menjadi faktor yang dominan, maka perusahaan harus secara berkesinambungan berusaha meningkatkan penjualannya sehingga diperoleh laba maksimal, misalnya dengan memberikan mutu produk yang berkualitas dan pelayanan yang paling baik. Walaupun debt to equity ratio berpengaruh negatif namun tidak signifikan terhadap harga saham, tetapi perusahaan harus tetap memperbaiki dan mengembangkan hubungan baik dengan konsumen, misalnya membuat program potongan harga jika konsumen membayar hutang tepat waktu.

\section{KETERBATASN DAN SARAN}

Penggunaan dan pemilihan sampel yang dilakukan dalam penelitian ini dapat menyebabkan bahwa hasil penelitan ini tidak mencerminkan kondisi secara keseluruhan dari populasi.Penelitian selanjutnya diharapkan dapat menambahkan atau menggunakan variabel lain untuk mengetahui faktor apa saja yang dapat mempengaruhi harga saham.Penelitian ini diharapkan dapat digunakan sebagai tambahan referensi bagi penelitian selanjutnya dibidang yang sama yang akan dating untuk dikembangkan dan diperbaiki, misalnya dengan memperpanjang periode pengamatan sehingga dapat lebih mencerminkan hasil penelitian.

\section{DAFTAR PUSTAKA}

Agus, R. Sartono (2008). Manajemen Keuangan Teori Dan Aplikasi. Edisi Keempat, BPFE. Yogyakarta. 
Anoraga, Pandji dan Piji Pakarti (2003). Buku Pintar Pasar Modal Indonesia. Mediasoft Indonesia. Jakarta.

Fahmi, Irham dan Hadi. (2011). Analisis Kinerja Keuangan.Edisi Pertama. Alfabeta, Bandung.

Harahap, Sofyan Syafri. (2011). Analisis Kritis atas Laporan Keuangan. PT. Raja Grafindo Persada. Jakarta.

Hartono, Jogiyanto. (2009). Konsep \& aplikasi. Edisi Ketiga, BPF PLS (Partial last Square) untuk penelitian empiris. BPFE Yogyakarta

Helfret, E.A. (1999). Teknik Analisis Keuangan (Petunjuk Praktis Mengelola dan Mengukur Kinerja Perusahaan).Edisi Kedelapan. Erlangga. Yogyakarta.

Hendri, Edduar. (2015). Pengaruh Debt To Asset Ratio, Long Term To Equity Ratio dan Net Profit Margin Terhadap Harga Saham Pada Perusahaan Yang Terdaftar di BEI. Jurnal Media Wahana Ekonomika. Vol. 12. No. 2. Juli.

Husnan, Suad (2001). Dasar-Dasar Teori portofoliodan analisis sekuritas,Edisi 5, UPP STIM YKPN. Yogyakarta.

Jogiyanto, (2003). Teori Portofolio dan Analisis Investasi. Edisi Ketiga. BPFE. Yogyakarta. , (2009). Teori Portofolio dan Analisis Investasi. Edisi Keenam, Badan Penerbit Fakultas Ekonomi Universitas Gadjah Mada. Yogyakarta.

Kasmir. (2012). Analisis Laporan Keuangan. PT. Raja Grafindo Persada, Jakarta.

(2015). Analisis Laporan Keuangan. PT. Raja Grafindo Persada. Jakarta.

Nasir. (2015). Analisis Laporan
Keuangan. PT. Raja Grafindo Persada. Jakarta.

Mulyadi. (2006). Manajemen

Keuangan: Pendekatan

Kuantitatif dan Kualitatif.

Bayumedia. Malang.

Rahardjo, Budi. (2009). Dasar-Dasar

Analisis Fundamental Saham:

Laporan Keuangan

Perusahaan.Cetakan Pertama.

Edisi Kedua. UGM Press. Yogyakarta.

Samsul, Mohamad. (2006). Pasar

Modal Dan Manajemen

Portofolio. Erlangga. Jakarta.

(2008). Pasar Modal Dan Manajemen Portofolio.

Erlangga. Jakarta.

(2015). Pasar Modal dan Manajemen Portofolio. Edisi

Kedua. Penerbit Erlangga, Jakarta.

Sudana, I Made. (2011). Manajemen Keuangan Perusahaan Teori \& Praktek, Erlangga. Jakarta.

Sunariyah, (2006). Pengantar Pengetahuan Pasar Modal, Edisi 5. UPP AMP YKPN, Yogyakarta.

Sunarto, (2001). Pengaruh Rasio Profitabilitas dan Leverage Terhadap Return Saham Perusahaan Manufaktur di BEI. Jurnal Bisnis Ekonomi.

Syamsuddin, Lukman. (2007). Manajemen Keuangan Perusahaan. Jakarta: PT. Raja Grafindo Persada.

(2011). Manajemen Keuangan Perusahaan: Konsep Aplikasi dalam Perencanaan, Pengawasan, dan Pengambilan Keputusan. Jakarta: PT. Raja Grafindo Persada.

Tjiptono Darmadji dan Hendy M. Fakhruddin. (2001). Pasar Modal Di Indonesia. Salemba Empat. Jakarta. 
. (2006). Pasar Modal Di Indonesia.

Salemba Empat. Jakarta.

. (20012). Pasar Modal Di Indonesia.

Edisi Ketiga, Salemba Empat. Jakarta.

Watung, Rosdian Widiawati dan Ilat ,Venjte. (2016). Pengaruh Return On Asset (ROA), Net Profit Margin (NPM) dan Earning Per Share (EPS) Terhadap Harga Saham Pada Perusahaan Perbankan di BEI periode 2011-2015. Vol. 4, No. 2, Juni

Werner R, Murhadi. (2013). Analisis Laporan Keuangan Lanjutan Proyeksi dan Valuasi Saham, Salemba Empat. Jakarta. 